\title{
Decreased Phytohemagglutinin-Induced Aggregation and C5a-Induced Chemotaxis of Human Newborn Neutrophils
}

\author{
ALAN D. MEASE, GERALD W. FISCHER, KENNETH W. HUNTER, AND \\ FREDERICK B. RUYMANN \\ Department of Pediatrics, Walter Reed Army Medical Center, Washington D. C. and Departments of Pediatrics and \\ Medicine, Uniformed Services University School of Medicine, Bethesda, Maryland, USA
}

\begin{abstract}
Summary
Phytohemagglutinin (PHA)-induced lectin aggregation, chemotactic response to $\mathrm{C} 5 \mathrm{a}$, and random migration were measured on paired samples of neutrophils obtained from human peripheral blood and cord blood of normal newborn infants. The mean aggregation rate $( \pm 1 \mathrm{SD})$ of adult neutrophils with $\mathrm{PHA}$ was 16.8 \pm 4.4 vs. $12.0 \pm 3.6$ for newborn neutrophils $(P<0.005)$, and the mean percent aggregation of adult neutrophils was $56.2 \pm 9.2$ vs. $45.6 \pm 8.3$ for newborn neutrophils $(P<0.005)$. Exposure to newborn plasma had no affect on adult neutrophil aggregation. Whereas vinblastine (VBL) decreased both the percent and rate of PHA-induced adult neutrophil aggregation, only the rate of newborn neutrophil aggregation was reduced by VBL. Newborn neutrophil chemotactic response to $\mathrm{C} 5 \mathrm{a}$, was reduced by $80 \%(P$ $<0.0025)$, and showed a positive correlation with percent PHAinduced aggregation $(r=0.6037, P<0.05)$. On the other hand, random migration was not significantly reduced and did not correlate with PHA-induced aggregation. These observations suggest that the decreased chemotactic responsiveness of newborn neutrophils may be due to developmental membrane differences which adversely affect the number and/or availability of C5a receptors. Lectin-induced aggregation studies of other chemotactic defects may identify similar differences.
\end{abstract}

\section{Speculation}

Although the precise nature of decreased newborn neutrophil chemotactic responsiveness remains unknown, these studies demonstrating decreased PHA-induced aggregation and decreased chemotactic response of newborn neutrophils suggest that developmental membrane differences in newborn neutrophil may adversely affect requisite premigratory membrane events. Persistence of these developmental membrane differences or their reappearance may be the basis of other chemotactic defects.

Decreased newborn neutrophil chemotactic responsiveness contributes to the newborn's impaired host defenses against bacterial infection and has been attributed to differences in the membrane properties of the newborn neutrophil (18). Such differences may adversely affect premigratory membrane events essential for normal chemotactic response. The chemotactic sequence is initiated by the binding of chemotactic factors to specific receptors on the neutrophil surface (27). Subsequent premigratory events include transmembrane fluxes of calcium and magnesium cations (8), changes in membrane surface charge (7), release of specific neutrophil granules $(2,9)$, changes in surface membrane configuration (5), accumulation of cellular cyclic guanosine $3^{\prime}, 5^{\prime}$-monophosphate (11), microtubule polymerization (26), increased hexose monophosphate shunt activity (10), and specific polarization of microfilaments (21). Despite normal random migration; chemotactic responsiveness of newborn neutrophils is decreased $(15,17$ 22). Developmental membrane differences which affect the binding of chemotactic factors or subsequent premigratory membrane events may explain the newborn neutrophil's decreased responsiveness.

To further evaluate this hypothesis, the authors used the plant lectin PHA, which binds to specific cell surface oligosaccharide receptors and forms cross bridges between cells, to probe surface membrane properties of the newborn neutrophil. In addition, concomitant determinations of random migration and chemotactic response to $\mathrm{C} 5 \mathrm{a}$ were made to define the relationship of PHAinduced aggregation to neutrophil movement.

\section{METHODS}

\section{PREPARATION OF NEUTROPHILS}

Citrated peripheral venous blood from healthy adult volunteers and venous cord blood from term newborn infants was collected and centrifuged on Ficoll-Hypaque gradients followed by dextran sedimentation (4). Erythrocytes were lysed with hypotonic saline and the resulting leuckocyte suspensions were washed twice in Hank's balanced salt solution (Microbiological Associates, Inc., Bethesda, MD) without $\mathrm{Ca}^{++}$and $\mathrm{Mg}^{++}$. Leucocytes obtained in this manner consisted of $94-98 \%$ neutrophils.

\section{LECTIN-INDUCED NEUTROPHIL AGGREGATION ASSAYS}

Neutrophils were adjusted to $5 \times 10^{6}$ cells $/ \mathrm{ml}$ in Gey's balanced salt solution (Microbiologicals Associates, Inc., Bethesda, MD) with $2 \%$ albumin and stored on ice. Neutrophil aggregation was done by a modification of the method of Maca and Hoak (16). Neutrophil suspension $(0.4 \mathrm{ml})$ were placed in cuvettes equipped with siliconized stirring bars. After temperature equilibration, 20 $\mu$ of PHA (PHA-P, $1 \mathrm{mg} / \mathrm{ml}$, Difco, Detroit, Ml) was added and aggregation was measured by changes in light transmission using Payton Dual Channel Aggregation Module (Payton Associates, Buffalo, NY) at $37.5^{\circ} \mathrm{C}$ with a stir rate of 900 RPM's. Experiments to determine the effect of newborn plasma on adult neutrophils were done by suspending adult cells in newborn plasma for 30 min during dextran sedimentation. Because chemotactic response, but not random migration is dependent on normal microtubular function (1), the effect of the antitubulin drug VBL on PHAinduced aggregation was evaluated. Three min before adding PHA, VBL (Eli Lilly, Indianapolis, Ind.) was added to cuvettes to make a final concentration of $6.15 \times 10^{-10} \mathrm{M}$.

The rate of aggregation was determined by measuring the maximum slope of each curve and is expressed as units $/ 2 \mathrm{~min}$. The percent aggregation was assessed at $5 \mathrm{~min}$ by converting the percent light transmission to change in optical density and multi- 
plying by 100 . The aggregation response for each experimental condition was the average of four aggregation curves.

\section{PREPARATION OF ZYMOSAN-ACTIVATED SERUM}

Zymosan-activated serum was prepared by a modification of the method of Vallota and Müller-Eberhard (25). Zymosan (Sigma Chemical Co., St. Louis, MO) was suspended in normal saline, boiled for $30 \mathrm{~min}$, then centrifuged at $2000 \times \mathrm{g}$ for $15 \mathrm{~min}$ and resuspended in normal saline to yield a final concentration of 10 $\mathrm{mg} / \mathrm{ml}$. Fresh normal human serum $(20 \mathrm{ml})$ was treated for $16 \mathrm{hr}$ at $4{ }^{\circ} \mathrm{C}$ with $1 \mathrm{M}$ epsilon-aminocaproic acid (EACA) (American Cyanamid Co., Pearl River, NY) to prevent C5a inactivation by anaphylatoxin inhibitor (25). The serum was then incubated at $37^{\circ}$ for $60 \mathrm{~min}$ with $0.1 \mathrm{ml}$ washed zymosan suspension per $\mathrm{ml}$ of serum. The reaction mixture was centrifuged at $2000 \times g$ for 30 min to remove zymosan.

\section{PREPARATION OF CSA}

Activated human serum $(10 \mathrm{ml})$ was fractionated by gel filtration through Sephadex G-100 as previously described (14). Fractions corresponding to the molecular weight range of 10,000 25,000 daltons were pooled. The partially purified fragment of the fifth component of complement, referred to hereafter as $\mathrm{C} 5 \mathrm{a}$, was tested for chemotactic activity at a 1:7.5 dilution of the original serum volume. Before assay for chemotactic response, the $\mathrm{C} 5 \mathrm{a}$ was further diluted 1:1 with veronal buffer.

\section{NEUTROPHIL CHEMOTAXIS AND RANDOM MIGRATION}

A modification of the neutrophil chemotaxis radioassay described by Gallin et al. (6) was used to measure chemotactic response and random migration of the newborn and adult neutrophil populations. Briefly, after removal of a aliquot of cells for aggregation studies, the remaining cells were adjusted to a concentration of $20 \times 10^{6}$ neutrophils $/ \mathrm{ml}$. One microcurie of $\mathrm{Na}_{2}$ $\mathrm{Cr}^{51} \mathrm{O}_{4}$ (New England Nuclear, Boston, MA) in 0.9\% saline was added per $10^{6}$ neutrophils, then the cells were incubated at $37^{\circ} \mathrm{C}$ for $60 \mathrm{~min}$ with gentle agitation. The cells were washed twice with $\mathrm{Ca}^{++}$and $\mathrm{Mg}^{++}$free Hank's balanced salt solution and resuspended to $3.0 \times 10^{6}$ neutrophils $/ \mathrm{ml}$ in Gey's BSS containing $2 \%$ human serum albumin. A $0.5 \mathrm{ml}$ volume was added to the upper compartment of a twe-compartment chemotaxis chamber; the lower compartment contained buffer or C5a. The two compartments were separated by two cellulose nitrate filters (Sartorius Membrane Filter, Gottingen, West Germany) with a mean pore diameter of $9 \mathrm{~m} \mu$ (upper) and $3 \mathrm{~m} \mu$ (lower). After a 3-hr incubation period, migration was determined as the counts per minute (CPM) of ${ }^{51} \mathrm{Cr}$ in the lower filter corrected for nonspecific uptake of the label (6). Each experimental condition was examined in quadruplicate chambers; newborns were always studied concomitantly with an adult control. Migration of neutrophils was expressed as the mean corrected cpm of the lower filters from four chambers.

\section{STATISTICS}

Student's $t$ test was used to evaluate the significance of differences between means. Percent PHA-induced aggregation was plotted as a function of C5a chemotactic response or random migration. Linear regression analysis was performed on these data using the method of least squares.

\section{RESULTS}

\section{PHA-INDUCED AGGREGATION ON NEWBORN AND ADULT} NEUTROPHILS

Representative PHA-induced neutrophil aggregation curves for adult and newborn neutrophils are shown in Figure 1. The mean rate of PHA-induced neutrophil aggregation was determined si-

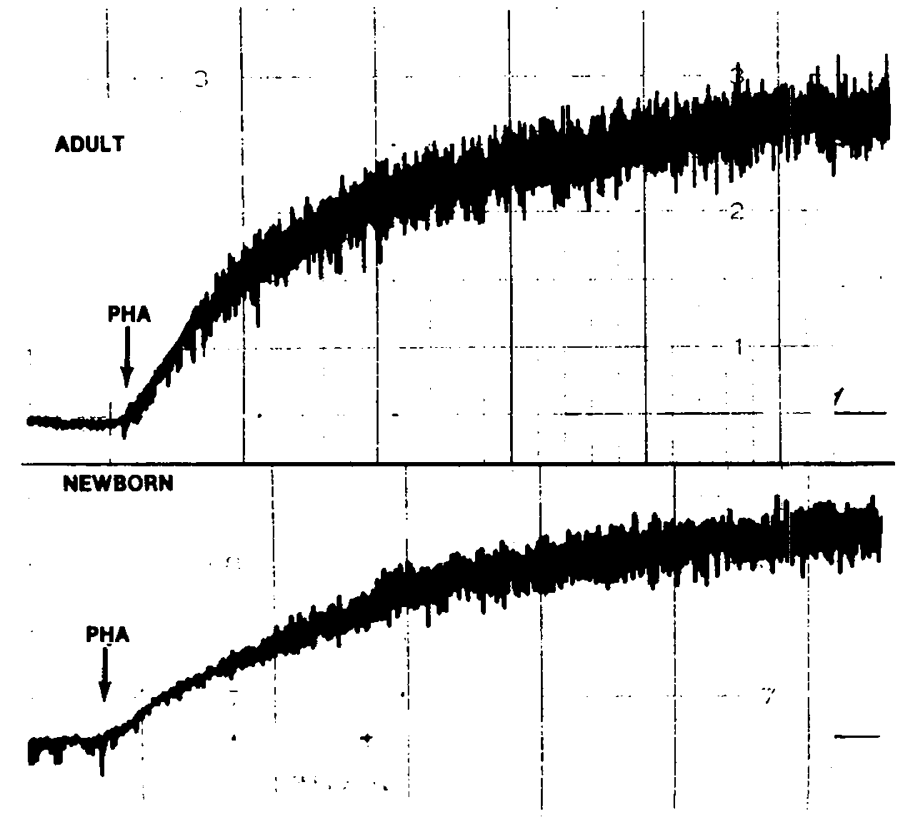

Fig. 1. Representative PHA-induced neutrophil aggregation curves. These curves are plots of changes in light transmission vs. time and were obtained simultaneously after addition of PHA to adult and newborn neutrophils.

multaneously in 14 normal adult controls and 14 normal term newborn infants. The mean rate (units $/ 2 \mathrm{~min}$ ) of adult neutrophil aggregation was $16.8 \pm 4.4$ and $12.0 \pm 3.6$ for newborn neutrophils $(P<0.005)$ (Table 1). The mean percent of adult PHA-induced neutrophil aggregation was $56.2 \pm 9.2 \%$ vs. $45.6 \pm 8.3 \%$ for newborn neutrophils $(P<0.005)$.

To evaluate the possibility of circulating plasma inhibitors to PHA-induced aggregation, the effect of newborn plasma on adult neutrophil PHA-induced aggregation was determined. Preincubation of neutrophils from five adults in newborn plasma for 30 min did not affect either the rate or percent of aggregation (Table 2).

Microtubules and microfilaments are important in the control of the location and mobility of cell membrane lectin receptors (3), and normal microtubular function is necessary for directed but not random movement (1). The authors, therefore, studied the effect of VBL on PHA-induced neutrophil aggregation. The preincubation of adult neutrophils with VBL decreased both the rate and percent of PHA-induced aggregation (Table 2). Although VBL did not decrease the percent PHA-induced aggregation of newborn neutrophil, it did decrase the rate of aggregation.

RANDOM MIGRATION AND CHEMOTACTIC RESPONSE TO C5A: CORRELATION WITH PHA-INDUCED AGGREGATION

As shown in Figure 2, the mean random migration values of adult and newborn neutrophils were $236 \pm 235$ corrected cpm in lower filter (cor cpm LF) and $141 \pm 106$ cor cpm LF, respectively $(P>0.05)$. By contrast, the mean chemotactic response of adult neutrophils was $2487 \pm 1320$ compared to $490 \pm 426$ cor cpm LF for newborn neutrophils $(P<0.0025)$. Whereas, the mean newborn random migration was $60 \%$ of the adult level, the chemotactic response to $\mathrm{C} 5 \mathrm{a}$ was only $20 \%$.

C5a chemotactic response, random migration, and PHA-induced aggregation were measured concomitantly in five adults, seven newborn infants, and two children with documented chemotactic defects. The percent PHA-induced aggregation was plotted against $\mathrm{C} 5 \mathrm{a}$ chemotactic response and random migration (Fig. 3). Linear regression analysis of these data revealed a positive correlation of PHA-induced aggregation with C5a response $(r=$ $0.6037)$, but no correlation with random migration $(r=0.0094)$. 
Table 1. Rate and percent of neutrophil aggregation in pairs of adults and newborn infants

\begin{tabular}{|c|c|c|c|c|}
\hline \multirow[b]{2}{*}{ Experimental pairs } & \multicolumn{2}{|c|}{ Rate of aggregation ${ }^{1}$} & \multicolumn{2}{|c|}{ Percent of aggregation ${ }^{1}$} \\
\hline & Adult neutrophils & Newborn neutrophils & Adult neutrophils & Newborn neutrophils \\
\hline 1 & $17.7 \pm 4.0$ & $10.0 \pm 1.7$ & $64.3 \pm 3.5$ & $48.4 \pm 6.1$ \\
\hline 2 & $14.4 \pm 1.3$ & $8.4 \pm 1.7$ & $49.8 \pm 9.5$ & $37.1 \pm 8.3$ \\
\hline 3 & $10.5 \pm 1.5$ & $11.0 \pm 1.5$ & $47.0 \pm 8.0$ & $45.7 \pm 4.7$ \\
\hline 4 & $26.2 \pm 4.9$ & $12.8 \pm 1.7$ & $70.0 \pm 11.6$ & $46.8 \pm 13.2$ \\
\hline 5 & $17.8 \pm 2.9$ & $8.2 \pm 1.7$ & $48.0 \pm 4.5$ & $44.5 \pm 4.6$ \\
\hline 6 & $12.2 \pm 1.7$ & $10.2 \pm 3.2$ & $42.0 \pm 5.8$ & $39.0 \pm 7.2$ \\
\hline 7 & $15.5 \pm 3.7$ & $12.5 \pm 3.0$ & $51.6 \pm 4.0$ & $38.0 \pm 9.3$ \\
\hline 8 & $16.5 \pm 1.3$ & $10.7 \pm 0.6$ & $61.6 \pm 7.4$ & $54.2 \pm 7.2$ \\
\hline 9 & $21.3 \pm 4.7$ & $15.7 \pm 1.5$ & $61.8 \pm 11.4$ & $52.5 \pm 2.8$ \\
\hline 10 & $22.0 \pm 0$ & $20.0 \pm 0$ & $54.2 \pm 3.5$ & $54.0 \pm 8.8$ \\
\hline 11 & $19.0 \pm 3.6$ & $17.7 \pm 0.6$ & $65.4 \pm 8.6$ & $51.0 \pm 3.0$ \\
\hline 12 & $15.8 \pm 0.5$ & $12.5 \pm 1.3$ & $71.0 \pm 11.3$ & $55.9 \pm 3.6$ \\
\hline 13 & $15.5 \pm 2.1$ & $11.2 \pm 1.5$ & $49.4 \pm 9.4$ & $26.0 \pm 2.7$ \\
\hline 14 & $10.4 \pm 1.9$ & $7.5 \pm 1.4$ & $51.3 \pm 3.5$ & $44.9 \pm 11.2$ \\
\hline \multirow{2}{*}{ Mean $\pm 1 \mathrm{SD}$} & $16.8 \pm 4.4$ & $12.0 \pm 3.6(71 \%)$ & $56.2 \pm 9.2$ & $45.6 \pm 8.3(81 \%)$ \\
\hline & \multicolumn{2}{|c|}{$P<0.005$} & \multicolumn{2}{|c|}{$P<0.005$} \\
\hline
\end{tabular}

'Mean \pm 1 SD of quadruplicate determinations. $P$ values represent the significance of the difference between means using Student's $t$ test. Numbers in parentheses indicate percent of adult values.

Table 2. Effect of newborn plasma and vinblastine on adult and newborn neutrophil aggregation

\begin{tabular}{|c|c|c|c|c|}
\hline \multirow[b]{2}{*}{ Adult neutrophils } & \multicolumn{2}{|c|}{ Rate of aggregation } & \multicolumn{2}{|c|}{ Percent aggregation } \\
\hline & & & & \\
\hline $\begin{array}{l}\text { Adult Plasma } \\
(\mathrm{n}=4)\end{array}$ & $16.6 \pm 3.8$ & & $56.5 \pm 7.3$ & \\
\hline $\begin{array}{l}\text { Newborn Plasma } \\
(n=4)\end{array}$ & $16.6 \pm 3.7$ & N.S.' & $56.3 \pm 9.2$ & N.S. ${ }^{1}$ \\
\hline \multicolumn{5}{|l|}{ Adult neutrophils } \\
\hline Control $(n=5)$ & $17.1 \pm 4.1$ & & $42.4 \pm 6.2$ & \\
\hline Vinblastine $(n=5)$ & & $P<0.02$ & & $P<0.005$ \\
\hline \multicolumn{5}{|l|}{$\begin{array}{l}\text { Newborn neutro- } \\
\text { phils }\end{array}$} \\
\hline $\begin{array}{l}\text { Control }(n=5) \\
\text { Vinblastine }(n=5)\end{array}$ & $10.7 \pm 2.2$ & N.S.' & $\begin{array}{l}33.8 \pm 7.0 \\
281+63\end{array}$ & $P<0.02$ \\
\hline Vinblastine $(n=5)$ & $7.6 \pm 1.7$ & & $28.1 \pm 6.3$ & \\
\hline
\end{tabular}

${ }^{1}$ N.S. $=$ not significant.

\section{DISCUSSION}

Lectins have been classically used to induce cell aggregation by binding to specific surface oligosaccharides and forming intercellular bridges. Lectin-induced cell aggregation has been used to detect subtle differences in the membrane characteristics of transformed tumor cells (23). The results of this study suggest that human newborn neutrophils have unique membrane properties reflected in decreased PHA-induced neutrophil aggregation. Cellular factors which can affect cell aggregation include: the number, distribution, and mobility of surface lectin receptors; cell surface charge and cell surface deformability; and surface membrane configuration (19). These cellular factors ultimately may influence lectin-induced cell aggregation by altering surface receptor numbers or availability. Because microtubule function influences surface receptor availability by change in their distribution and mobility, the authors studied the affect of the antitubulin drug VBL on PHA-induced neutrophil aggregation. Whereas VBLtreated adult neutrophils demonstrated significantly less PHAinduced aggregation, newborn neutrophil aggregation was less affected by VBL. This suggests either a preexisting abnormality in newborn neutrophil microtubule function, or less sensitivity of newborn neutrophil to VBL treatment.

Craddock et al. (5) using standard aggregometry techniques have shown that $\mathrm{C} 5 \mathrm{a}$ induces neutrophil aggregation in vitro. $\mathrm{C} 5 \mathrm{a}$ induced neutrophil aggregation is involved in leucostasis with

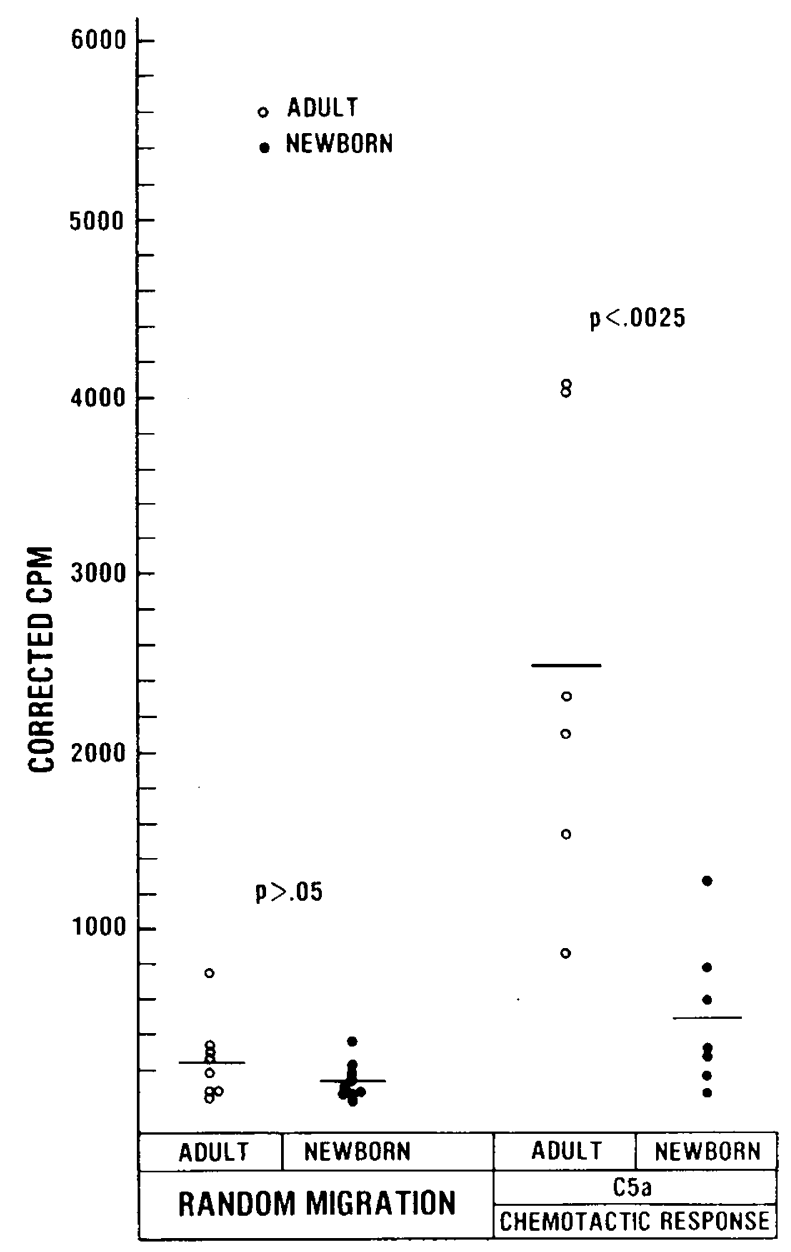

Fig. 2. Comparisons of adult and newborn random migration and chemotactic response to C5a. Each point represents mean $\pm 1 \mathrm{SD}$ of quadruplicate determinations of individual adults and newborns. Lines represent group means.

attendant neutropenia when intravascular complement activation occurs (20). Therefore, because neutrophil aggregation by C5a occurs in vivo, this may be important in normal neutrophil mobilization from the intravascular space to the site of inflammation. 

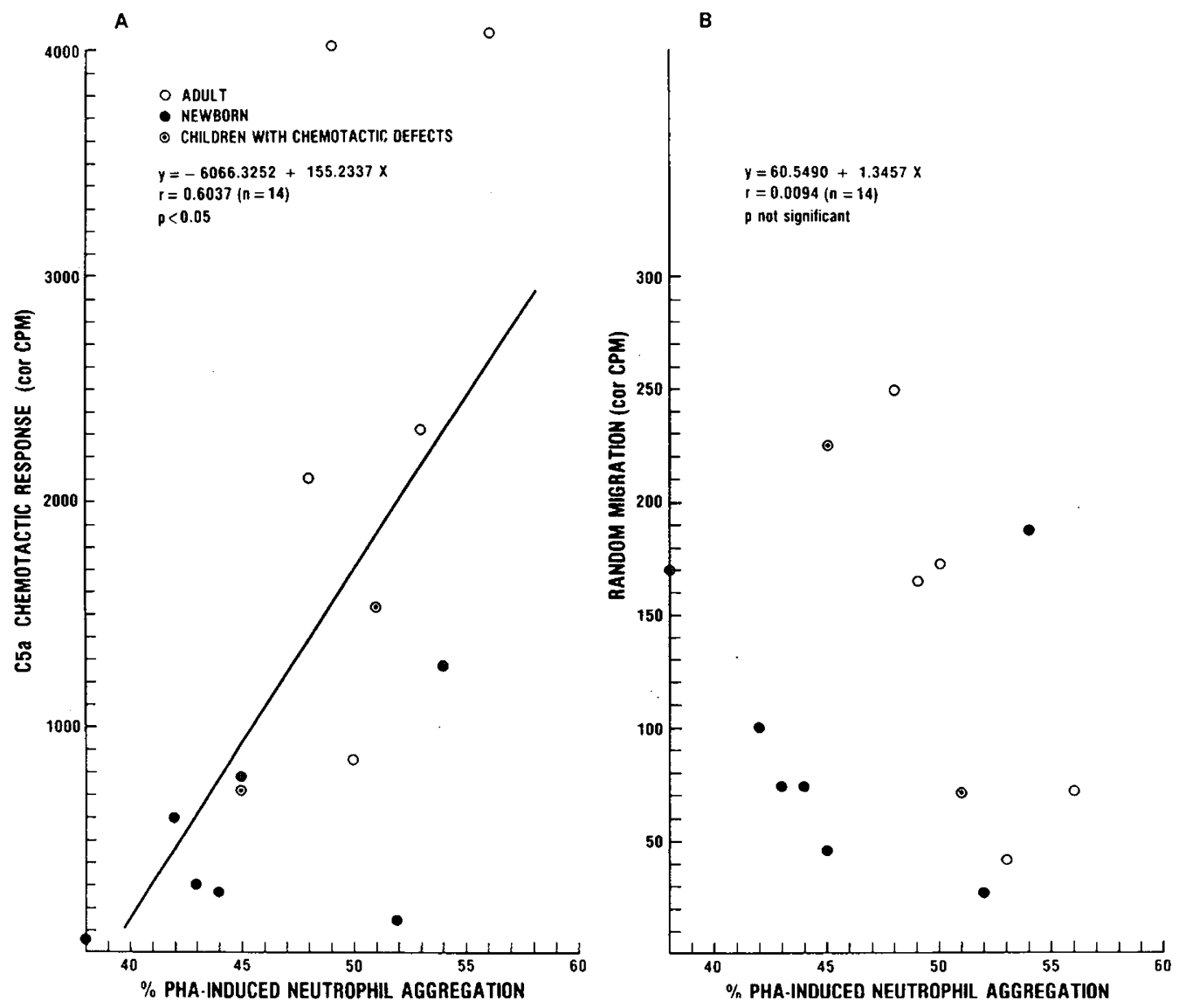

Fig. 3. Scatter diagrams of PHA-induced aggregation verses $C 5$ a chemotactic response $(A)$ and random migration $(B)$. Regression Line derived by the method of least squares.

The demonstration of positive correlation between PHA-induced aggregation and $\mathrm{C} 5 \mathrm{a}$-induced chemotactic response, and the lack of correlation with random migration, suggests a relationship between the quantity and/or availability of PHA and C5a receptors. Little is known about the neutrophil membrane $\mathrm{C} 5 \mathrm{a}$ receptor, whereas the PHA receptor is known to be an oligosaccharide (19). The relationship between $\mathrm{C} 5 \mathrm{a}$ receptors and lectin receptors is strengthened by the inhibition of C5a-induced lysosomal enzymes released from rabbit neutrophils by concanavalin $A$ (Con A) (13). In addition, like $\mathrm{C} 5 \mathrm{a}(2,9)$, Con $\mathrm{A}$ induces a selective discharge of specific granules $(12,13)$. Further support of this relationship derives from evidence that lectins can initiate a chemotactic response when bound to neutrophil membrane receptors (24).

Although the light-scattering technique adapted from standard platelet aggregometry has previously been applied to the study of lectin-induced aggregation of tumor cells by Maca and Hoak (16) and to C5a-induced aggregation of neutrophils by Craddock et al. (5), this study is the first to apply it to PHA-induced aggregation of normal neutrophils and neutrophils with a known decrease in chemotactic response, i.e., newborn neutrophils. The decreased PHA-induced aggregation of newborn neutrophils as well as the correlation between decreased PHA-induced aggregation and decreased $\mathrm{C} 5 \mathrm{a}$ chemotactic response leads to the hypothesis that the decreased $\mathrm{C} 5 \mathrm{a}$ response of the newborn neutrophil is due to developmental membrane differences affecting the number and/ or availability of C5a receptors. Comparisons of adult and newborn neutrophil $\mathrm{C} 5 \mathrm{a}$-induced aggregation and $\mathrm{C} 5 \mathrm{a}$ binding studies are presently underway to test this hypothesis.

\section{REFERENCES AND NOTES}

1. Bandmann, U., Rydgren, L., and Norberg, B.: The difference between random movement and chemotaxis. Effects of antitubulins on neutrophil granulocyte locomotion. Exp. Cell Res., 88: 63 (1974).
2. Becker, E. L., Showell, H. J., Hensen, P. M. and Hsu, L. S.: The ability of chemotactic factors to induce lysosomal enzyme release $\mathrm{I}$. The characteristics of the release, the importance of surfaces, and the relation of enzyme release to chemotactic responsiveness. J. Immunol., 112: 2047 (1974).

3. Berlin, R. D and Ukena, T. E. Effect of colchicine and vinblastine on the agglutination of polymorphonuclear leukocytes by concanavalin A. Nature New Biol., 238: 120 (1972)

4. Böyum, A.: Isolation of mononuclear cells and granulocytes from human blood. Isolation of mononuclear cells by one centrifugation and of granulocytes by combining centrifugation and sedimentation at $1 \mathrm{~g}$. Scand. J. Clin. Lab. Invest. Suppl., 97: 77 (1968).

5. Craddock P. R., Hammerschmidt, D., White, J. G., Dalmesso, A. P., and Jacob, H. S.: Complement (C5a)-induced granulocyte aggregation in vitro. J. Clin. Invest., 60: 260 (1977)

6. Gallin J. I., Clark, R. A., and Kimball, H. R.: Granulocyte chemotaxis: an improved in vitro assay employing ${ }^{51} \mathrm{Cr}$-labeled granulocytes. J. Immunol., 110 : 233 (1973).

7. Gallin, J. I., Durocher, J. R., and Kaplan, A. P.: Interaction of leucocyte chemotactic factors with the cell surface I. Chemotactic factor-induced changes in human granulocyte surface charge. J. Clin. Invest., 55: 967 (1975).

8. Gallin, J. I., and Rosenthal, A. S.: The regulatory role of divalent cations in human granulocyte chemotaxis. Evidence for an association between calcium exchanges and microtubule assembly. J. Cell Biol., 62: 594 (1974).

9. Gallin, J. I., Wright, D. G. and Schiffman, E.: Role of secretory events in modulating human neutrophil chemotaxis. J. Clin. Invest., 62: 1364 (1978).

10. Goetz, E. J., and Austen, K. F.: Stimulation of human neutrophil leucocyte aerobic glucose metabolism by purified chemotactic factors. J. Clin. Invest. 53: 591 (1974).

11. Hatch, G. E., Nichols, W. K. and Hill, H. R.: Cylic nucleotide changes in human neutrophils induced by chemoattractants and chemotactic modulators. J. Immunol., 119: 450 (1977).

12. Hawkins, D.: The effect of lectins on lyosomal enzyme release from neutrophilic leucocytes. J. Immunol., 113: 1864 (1974).

13. Hoffstein, S., Soberman, R., Goldstein, l., and Weissmann, G.: Concanavalin A induces microtubule assembly and specific granule discharge in human polymorphonuclear leucocytes. J. Cell Biol., 68: 781 (1976).

14. Hook, W. A., Siraganian, R. P. and Wahl, S. M.: Complement-induced histamine release from human basophils $I$. Generation of activity in human serum. J Immunol., 114: 1185 (1975).

15. Klein, R. B., Fischer, T. J., Gard, S. E., Biberstein, M., Rich, K. C., and Stiehm E. R.: Decreased mononuclear and polymorphonuclear chemotaxis in human newborns, infants, and young children. Pediatrics, 60: 467 (1977).

16. Maca, R. D., and Hoak, J. C.: Improved method for quantitation of concanavalin 
A-induced agglutination. J. Natl. Cancer Inst., 52: 365 (1974).

17. Miller, M. E.: Chemotactic function in the human neonate: humoral and cellular aspects. Pediatr. Res., 5: 487 (1971).

18. Miller, M. E.: Developmental maturation of human neutrophil motility and its relationship to membrane deformability. In: J. A. Bellanti, D. H. Dayton: The Phagocytic Cell in Host Resistance. (Raven Press, New York, 1975) p. 295.

19. Nicholson, G. L.: The interactions of lectins with animal cell surfaces. In: G. H. Bourne and J. F. Danielli: International Review of Cytology (Academic Press, New York, 1974) p. 89

20. O'Flaherty J. T., Showell, H. J., and Ward, P. A.: Neutropenia induced by systemic infusion of chemotactic factors. J. Immunol., 118: 1586 (1977).

21. Oliver; J. M., Krawiec, J. A., and Becker, E. L.: The distribution of actin during chemotaxis in rabbit neutrophils. J. Reticul. Soc.. 24: 697 (1978).

22. Pahwa, S. G., Pahwa, R., Grimes, E., and Smithwick, E.: Cellular and Humoral components of monocyte and neutrophil chemotaxis in cord blood. Pediatr. Res. 11: 677 (1977).

23. Rosenblith, J. Z., Ukena, T. E., Yin, H. H., Berlin, R. D., and Karnovsky, M. J.: A comparative evaluation of the distribution of concanavalin A-binding sites on the surfaces of normal, virally-transformed, and protease-treated fibroblasts. Proc. Nat. Acad. Sci., 70: 1625 (1973).
24. Till, G., Lenhard, V., and Gemso, D.: Chemotactic activity of lectins in vitro. $Z$. Immuno-Forsch., 154: 173 (1978).

25. Vallota, E. H., and Müller-Eberhard, H. J.: Formation of $\mathrm{C} 3 \mathrm{a}$ and C5a anaphylatoxins in whole human serum after inhibition of the anaphylatoxin inactivator. J. Exp. Med., 137: 1109 (1973)

26. Weissmann, G., Goldstein, I., Hoffstein, S., and Tsung, P. K.: Reciprocal effects of CAMP and cGMP on microtubule dependent release of lysosomal enzymes. Ann. N.Y. Acad. Sci., 254: 750 (1975).

27. Williams, L. T., Snyderman, R.. Pike, M. C., and Lefkowitz, R. F.: Specific receptor sites for chemotactic peptides on human phymorphonuclear leucocytes. Proc. Nat. Acad. Sci., 74: 1204 (1977).

28. The authors thank Ms. Doris Burgess for her excellent technical assistance and Dr. August J. Salvado for his helpful suggestions.

29. This research was supported, in part, by the Clinical Investigation Service, Walter Reed Army Medical Center, Washington, D. C.

30. The opinions expressed herein are those of the authors and do not necessarily represent the views of the Department of the Army or the Department of Defense.

31. Received for publication October 7,1978

32. Accepted for publication March 7, 1979. 